\title{
Peran Sains dan Teknologi dalam Membangun Peradaban Islam
}

\author{
Fahmi Amhar ${ }^{*}$, Anas Puri², dan Ardiansyah ${ }^{3}$ \\ ${ }^{1}$ Badan Informasi Geospasial, Bogor, Indonesia \\ 2Universitas Islam Riau, Pekanbaru, Indonesia \\ 3Universitas Lancang Kuning, Pekanbaru, Indonesia
}

\section{ARTICLE INFO}

\section{Keywords}

Sains, Teknologi,

Peradaban, Islam

*Correspondence

fahmi.amhar@big.go.id

\section{Article History}

Received 31 March 2018

Accepted 28 April 2018

Published on-line 10 May 2018

\section{ABSTRACT}

Peradaban adalah suatu susunan masyarakat yang kompleks yang dicirikan oleh pembangunan perkotaan, stratifikasi sosial yang diterapkan oleh elit budaya, sistem komunikasi simbolik (misalnya, sistem penulisan), dan pemisahan yang dirasakan dari dan dominasi atas lingkungan alam. Peradaban Islam adalah peradaban yang dibangun di atas dasar aqidah Islam, bertujuan sesuai maksud-maksud (maqashid) syariah, dan diwujudkan dengan mencontoh perbuatan (sunnah) Nabi Muhammad, para shahabatnya serta ramburambu halal dan haram. Islam berada di puncak peradaban saat sistem Khilafah masih tegak, meski mengalami pasang surut. Pada tulisan ini dibahas kondisi dunia sains dan teknologi terkini di Indonesia dan dunia, komparasinya dengan sistem Islam saat berada di puncak peradaban, dan tawaran solutif pengembangan sains dan teknologi saat ini.

\section{PENDAHULUAN}

Ada banyak persoalan yang membelit negara berkembang, (dan hampir seluruh negeri muslim adalah negara berkembang, meski spectrum GDB dan pendapatan perkapita mereka cukup lebar). Dan ada kemiripan persoalan mereka bila dikaitkan dengan sains dan teknologi, yaitu: (1) mereka tidak memiliki kemandirian, sebagian besar teknologi yang mereka gunakan didatangkan dari luar dengan segala persoalannya; (2) Sumber Daya Riset mereka kurang produktif atau kurang termanfaatkan; (3) Kalaupun ada sains dan teknologi yang dibuat oleh mereka, sains dan teknologi tersebut belum khas, bahkan belum banyak sesuai dengan karakter dan kebutuhan mereka.

Adapun yang pertama, sering dimaklumi karena persoalan ekonomi yang membelit mereka saat awal membangun. Ketiadaan modal memaksa mereka untuk mengundang investor dari negara maju. Investor tersebut tentu saja memberi syarat yang akan menguntungkan mereka selanjutnya, yakni membawa teknologi yang mereka miliki, atau memaksakan skema kerjasama yang terus menguntungkan mereka di masa depan, misalnya skema bagi hasil atas eksploitasi sumberdaya alam. Setelah 44 tahun Toyota berkiprah di Indonesia (dari 1974), sampai hari ini Indonesia praktis belum memiliki mobil nasional. Artinya, slogan transfer teknologi yang selama ini didengung-dengungkan untuk memuluskan masuknya investor asing, ternyata hanya sedikit sekali menjadi realitas. Demikian juga, penguasaan tambang-tambang raksasa seperti Freeport atau Newmont juga sekali tiga uang. Sangat sulit bagi negeri ini untuk lepas dari jerat perjanjian yang dibuat puluhan tahun yang lalu yang sangat lebih menguntungkan investor asing.

Kemudian yang kedua, lebih sering terjadi karena sikap mental akibat terjajah yang sekian lama, sehingga kehilangan rasa percaya diri. Semua yang berasal dari negara maju dianggap lebih baik. Inovasi yang dihasilkan oleh peneliti domestik dianggap kurang berkualitas, atau masih "belajar" sehingga tidak banyak yang sampai mengalir ke manufaktur atau industri massal. Bahkan seandainya banyak kaum terpelajar kita yang menyelesaikan studinya di negara maju, atau bahkan telah sukses berkarir di sana, ketika pulang ke tanah airnya, kurang mendapatkan apresiasi sebagaimana orang-orang asing yang sebenarnya tidak lebih pandai dari saudara kita tadi. Regulasi yang ada juga sering sangat longgar untuk produk impor, tetapi terlalu ketat untuk inovasi peneliti kita sendiri. Pada saat yang sama, banyak regulasi keuangan yang membonsai sedemikian rupa sehingga karya-karya peneliti kita yang ASN sangat sulit untuk dibawa ke tahap komersialisasi. Contoh-contoh ini amat banyak. Mobil listrik ciptaan Dr. Ricky Elison tidak mendapat ijin kelaikan jalan dengan alasan tidak lulus uji emisi (padahal mobil listrik memang tidak ada emisinya). Terapi ECCT (Electro Capacity for Cancer Therapy atau lebih dikenal dengan rompi/helm untuk terapi kanker) ciptaan Dr. Warsito oleh Kementerian Kesehatan dilarang untuk digunakan dengan alasan belum uji klinis, padahal banyak alat terapi suplementer dari negara lain bebas diperdagangkan. Prof Muhammad Nurhuda, dari Universitas Brawijaya tidak mungkin mendapat dana riset dari negara untuk kompor biomassnya yang sudah banyak mendapatkan penghargaan, karena beliau adalah dosen fisika, sedang urusan kompor adalah lahan kompetensi teknik mesin. Demikian pula Oskar Riandi, perekayasa dari BPPT yang menemukan algoritma dan software untuk membuat transkripsi otomatis dari percakapan Bahasa Indonesia, sulit untuk mendapatkan royalti dari penjualan software buatannya, karena Peraturan Menteri Keuangan masih belum memuat hal-hal semacam itu. Oskar akhirnya memutuskan untuk meninggalkan status PNS nya dan sepenuhnya menjadi orang swasta. 
JKPIs, Vol. 1 No. $1,2018 \mid 18$

Pada gambar berikut ini tampak bahwa Sumber Daya Riset Indonesia hanya sekitar $0.2 \%$ dari GDP, bandingkan dengan Israel yang $4.2 \%$ atau lebih dari 20 kalinya. Kemudian dari sisi SDM nya, bila yang dihitung harus minimal berpendidikan S2, maka saintis kita hanya sekitar 100 orang per sejuta penduduk. Bandingkan dengan Finlandia yang memiliki 7000 saintis per sejuta penduduk, atau China yang memiliki 1200 saintis per sejuta penduduk. Meski demikian karena China memiliki populasi yang sangat besar, jumlah absolut saintis China masih jauh di atas Finlandia. Sedang Indonesia, karena rasio sainstisnya per sejuta penduduk memang terlalu kecil, jumlah absolutnya masih lebih kecil dari Finlandia atau bahkan Singapura.

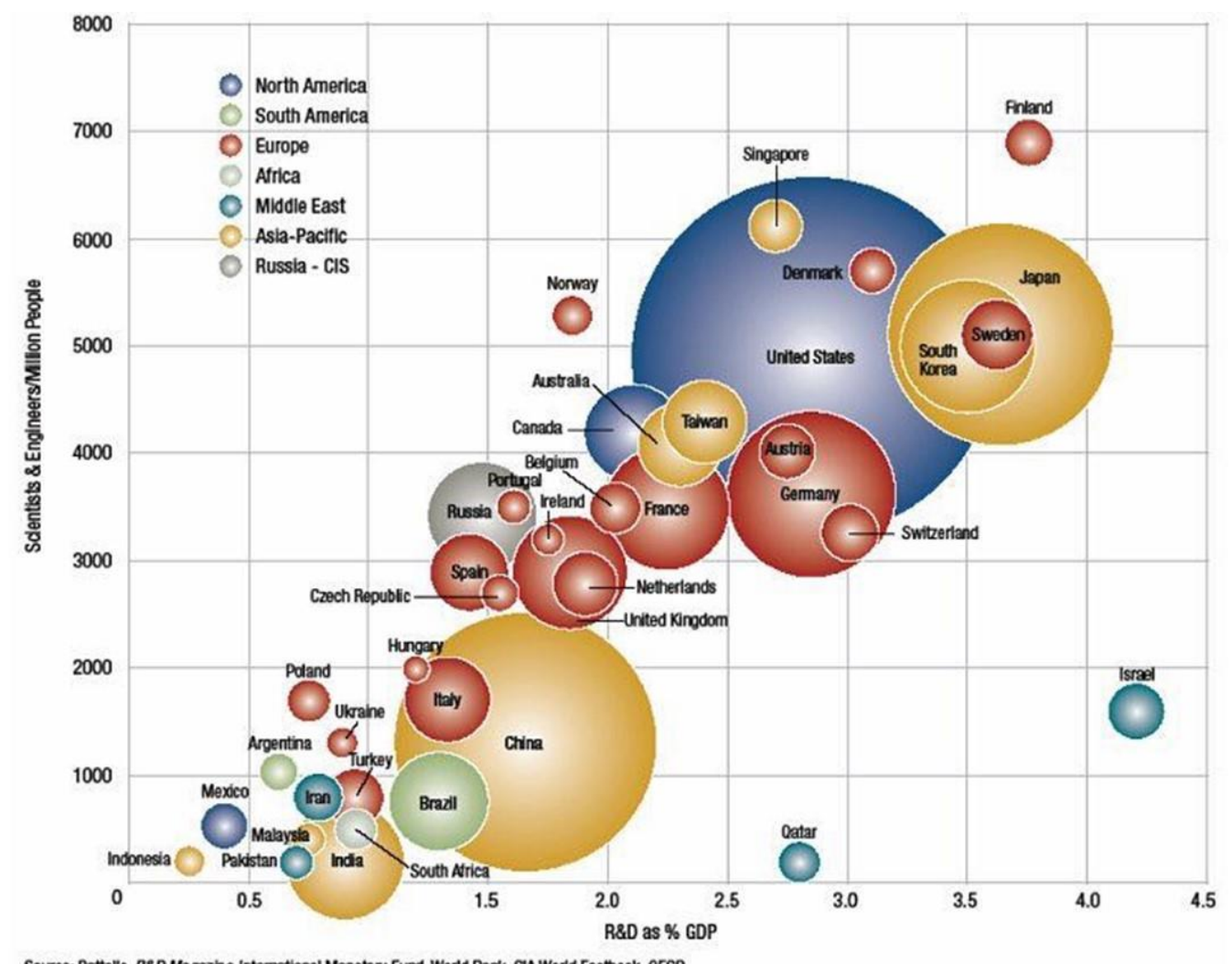

Source: Battelle, R\&D Magezhe, international Monetary Fund, World Bank, CA World Factbook, OECO

Gambar 1. Rasio anggaran riset terhadap GDP dan rasio jumlah saintis

Adapun persoalan ketiga, para peneliti di negeri-negeri muslim masih sangat jarang yang menghasilkan karya inovatif yang khas. Ternyata Islam yang kental dianut oleh mereka belum banyak memberikan pengaruh yang tampak pada karya mereka. Riset mereka tidak banyak bedanya dengan riset yang dilakukan non muslim di negeri-negeri sekuler. Kalaupun ada riset yang bernuansa Islam, itu lebih pada aplikasi riset, semisal riset Halal. Adapun substansinya, ontologi dan epistemologinya tidak ada yang baru. Secara substansi, seekor sapi yang disembelih normal dengan yang disembelih untuk berhala, tidak ada bedanya, sehingga tidak bisa dilacak jejaknya. Namun sembelihan untuk berhala tetap dihukumi haram.

Dari tiga hal ini, tampak bahwa kita membutuhkan suatu dorongan baru, agar persoalan kemandirian, sumber daya riset dan paradigma riset Islam dapat menjadi arus utama sains dan teknologi di dunia Islam, agar peradaban Islam yang dicita-citakan bisa benar-benar terwujud.

Peradaban sendiri definisikan sebagai suatu susunan masyarakat yang kompleks yang dicirikan oleh pembangunan perkotaan, stratifikasi sosial yang diterapkan oleh elit budaya, sistem komunikasi simbolik (misalnya, sistem penulisan), dan pemisahan yang dirasakan dari dan dominasi atas lingkungan alam. Peradaban Islam adalah peradaban yang dibangun di atas dasar aqidah Islam, bertujuan sesuai maksud-maksud (maqashid) syariah, dan diwujudkan dengan mencontoh perbuatan (sunnah) Nabi Muhammad, para shahabatnya serta rambu-rambu halal dan haram. Islam berada di puncak peradaban saat sistem Khilafah masih tegak, meski mengalami pasang surut. Dengan demikian pertanyaan utama dalam penelitian ini adalah bagaimana komparasi sains dan teknologi saat ini dengan sistem Islam saat berada di puncak peradaban, dan tawaran solutif pengembangan sains dan teknologi saat ini.

\section{METODE PENELITIAN}

Penelitian ini menggunakan banyak data sekunder baik dari referensi standar maupun dari media berita populer. Lebih banyak referensi dengan latar belakang sejarah dan latar belakang laporan perkembangan riset, sains dan teknologi. Titik penekanan lebih pada analisis yang bersifat deskriptif kualitatif. Materi yang dituliskan ini sudah didiskusikan di banyak sekali forum ilmiah.

\section{HASIL DAN PEMBAHASAN}

\subsection{Komparasi Sains dan Teknologi Sekuler vs Islam}

Sebagian orang berpendapat, sains dan teknologi (saintek) bebas nilai sehingga dapat diambil dari mana saja. Sementara sebagian lain berpendapat sebaliknya. Bahwa, saintek harus difilter dan "diislamkan" lebih dulu. Pada umumnya, mereka yang menganggap saintek bebas nilai, memberi contoh bagaimana Rasulullah Shallallahu 'alaihi wasallam menyuruh para Sahabat belajar sampai ke China -yang tentunya bukan belajar ilmu agama tetapi saintek- sehingga mereka dapat menguasai matematika, pembuatan kertas hingga cara membuat mesiu. Saintek ini kemudian juga dikembangkan lebih lanjut secara kreatif oleh para ilmuwan Muslim. 
JKPIs, Vol. 1 No. 1, 2018| 19

Sedang yang menganggap saintek tidak bebas nilai seperti teori evolusi Darwin, determinisme Newton yang menolak peran Tuhan dalam mekanisme alam hingga penggunaan senjata pemusnah massal. Lahirnya teori-teori ekonomi komunis maupun neoliberal pun dianggap bukti bahwa saintek tidak bebas nilai.

Asumsinya, mahzhab saintek yang bersandar pada sesuatu di luar Islam terbukti bermasalah, dan ilmuwan yang menekuninya lebih sering dihitung sebagai ilmuwan sekuler, yakni ilmuwan yang memandang bahwa agama tidak perlu dilibatkan dalam pengaturan urusan kehidupan publik. Faktanya, dua kelompok tadi memang ada. Di mana kekeliruan menaruh suatu objek saintek pada suatu kelompok yang akhirnya berujung pada kefatalan.

Untuk melakukan komparasi mazhab ristek tersebut memang perlu diperjelas parameter yang dibandingkan. Salah satu parameter yang paling menyeluruh adalah telaah menurut tiga aspek filsafat ilmu yaitu: ontologi, epistemologi dan aksiologi. Ontologi membahas hal-hal yang terkait mengapa suatu penelitian atas objek tertentu perlu dilakukan. Epistemologi membahas tentang tata cara suatu penelitian harus dilakukan. Sedang aksiologi membahas sejauh mana hasil penelitian dapat digunakan. Ilmuwan Muslim

\subsubsection{Paradigma Ilmuwan Sekuler}

Ilmuwan sekuler akan berontologi pada kepuasan batin peneliti dan/atau untuk kebutuhan masyarakat kapitalis untuk memaksimalkan keuntungan dengan meminimalkan biaya. Mereka hanya tertarik meneliti apa saja yang memberikan kepuasan batin, memenuhi selera konsumsi, tanpa harus selalu memperhitungkan rambu-rambu agama. Beberapa riset tetap dipagari dengan etika, namun ini juga karena alasan agar investasi yang telah dikeluarkan tidak hangus akibat ditolak masyarakat. Karenanya, tak sedikit usaha yang dikeluarkan untuk suatu riset yang tidak menjawab masalah apa-apa kecuali kepuasan peneliti. Riset bahkan memperbudak manusia pada teknologi, atau "menjajah" suatu masyarakat pada pihak yang menguasai teknologi.

Sekadar contoh. Banyak penelitian terdepan di bidang matematika, kosmologi, palaeobiologi atau juga ilmu-ilmu sosial yang sudah kabur hubungannya dengan realitas kehidupan saat ini. Setidaknya, para ilmuwan yang menggelutinya kesulitan menjelaskan kepada orang awam akan manfaat risetnya itu selain memenuhi rasa ingin tahu. Tidak sedikit riset-riset yang dibiayai korporasi besar terus ingin mendapatkan saintek yang makin efisien untuk menghasilkan keuntungan besar. Hasilnya mesinmesin raksasa yang makin efisien untuk mengeruk sumberdaya alam tapi merugikan rakyat kecil dan melahirkan dampak lingkungan.

Secara epistemologi, ilmuwan sekuler pada dasarnya ingin bebas dan tidak ingin diatur, sekalipun oleh hukum. Contoh nyata; di masa NAZI dulu, Hitler memerintahkan melakukan riset antropologi terapan untuk mengenali secara cepat etnis non-Arian murni pada masyarakat Jerman. Riset ini bertujuan mengidentifikasi "bibit musuh dalam selimut" dalam masyarakat Jerman. Riset dilakukan dengan melakukan pengukuran biometris secara paksa pada orang-orang yang dijadikan sampelnya. Terkadang riset ini dibumbui dengan penyiksaan, perlukaan hingga pembunuhan atas nama kemajuan ilmu pengetahuan.

Sedang secara aksiologinya, ilmuwan sekuler ingin mencari keuntungan sebanyak-banyaknya. Di dunia Barat, semua penemuan saintek boleh dipakai - sepanjang selaras dengan hukum yang berlaku (tentunya hukum sekuler yang menolak agama dalam pengaturan urusan publik). Wajar jika hasil saintek hanya untuk optimalisasi maksiat seperti: perjudian, pelayanan seks komersial, pembuatan khamr). Di Technical Univesity Munich Jerman bahkan ada program studi teknologi pembuatan bir. Dan dalam lingkup global, sains sekuler merasa baik-baik saja disalahgunakan dalam penjajahan atau eksploitasi alam yang berlebihan, yang berakibat menurunnya kualitas lingkungan hidup. Kalaupun hari-hari ini muncul kesadaran baru untuk menciptakan teknologi yang lebih ramah lingkungan, lagi-lagi itu didorong oleh motivasi bisnis.

\subsubsection{Paradigma Ilmuwan Islam dalam Peradaban Islam}

Berbeda dengan kalangan ilmuwan sekuler, ilmuwan Muslim seharusnya akan berontologi dengan (1) kebutuhan yang merupakan maqashid syariáh (tujuan syar'iyyah), tetapi dapat juga (2) terinspirasi suatu ayat Qur`an yang bermuatan pertanyaan yang dapat dikaji lanjut secara ilmiah, atau (3) termotivasi oleh suatu ayat Qur’an yang memberikan tantangan, yang mau tak mau berarti pengembangan saintek terkait.

Seorang ilmuwan Muslim akan tergelitik untuk meneliti sehingga seluruh kebutuhan yang termasuk hajatul udhowiyah (kebutuhan asasi seperti sandang-pangan-papan) dapat dipenuhi dengan baik. Selain itu, juga agar seluruh kewajiban/maqashid syar'iyyah dapat terlaksana. Konon, Imam Al-Khawarizmi mengembangkan aljabar karena ingin membantu membagi waris dengan akurat.

Kedua, ada ratusan ayat Qur'an yang seharusnya memberi inspirasi riset saintek pada ilmuwan Muslim. Bahkan ayat tentang surga saja masih dapat memberikan inspirasi riset, misalnya:

\section{“Di surga itu mereka diberi segelas minum yang campurannya adalah jahe." (Al-Insan [76]: 17).}

Seorang ilmuwan Muslim pantas tergelitik untuk meneliti jahe, ada apa di dalam jahe sehingga disebut sebagai campuran minuman ahli surga? Ayat ini mestinya mendorong di perguruan tinggi -perguruan tinggi negeri muslim, apalagi perguruan tinggi islam lahirnya pusat-pusat penelitian tentang jahe. Seberapa banyak anti oksidan di dalam jahe? Bagaimana jahe berpengaruh positif untuk melawan kanker? Seberapa banyak jahe mengandung zat anti-aging? Dan sebagainya.

Ketiga, seorang Muslim -apalagi ilmuwan- akan merasa tertantang oleh ayat-ayat Qur'an seperti ini:

"Kalian adalah umat yang terbaik yang dilahirkan untuk manusia, menyuruh kepada yang makruf, dan mencegah dari yang munkar, dan beriman kepada Allah. ..." (Ali Imran [3]: 110).

Dua ayat di atas mendorong kaum Muslim untuk menjadi yang terbaik, yakni yang mampu menyuruh yang makruf dan mencegah yang munkar di dunia, sedang untuk itu diperlukan kekuatan apa saja. Kemudian secara epistemologi, ilmuwan Muslim akan melakukannya dengan cara-cara yang dibatasi syariat: (1) tidak menolak suatu pernyataan yang harus diimani secara aqidah (yang tentu saja memerlukan dalil qath'i), dan (2) berjalan sesuai koridor perintah dan larangan. Seorang ilmuwan Muslim juga tak akan membiarkan suatu maksiat terjadi sekalipun demi kemajuan ilmu pengetahuan. Oleh karena itu, percobaan cloning pada 
JKPIs, Vol. 1 No. $1,2018 \mid 20$

manusia tetap dilarang, karena bila berhasil berkonsekuensi melahirkan manusia tanpa nasab (yang akan menimbulkan berbagai masalah syara').

Sedang secara aksiologi, produk saintek ilmuwan Muslim seharusnya dikembangkan atau didesain untuk kemanfaatan sebesar-sebesarnya sesuai syariat, bukan sebaliknya. Contoh; matematikawan Muslim yang mempelajari teori permutasi ataupun neuronal network untuk melakukan prediksi kejadian, tak akan menggunakan ilmu itu (haram hukumnya) untuk memenangkan perjudian. Walhasil, banyak perbedaan antara saintek yang dikembangkan dalam sistem Islam dan sekuler. Masalahnya, bagaimana kesediaan ilmuwan Muslim mengambil sikap dalam masalah ini?.

\subsection{Tawaran Solutif Pengembangan Sains dan Teknologi}

Science (from Latin scientia, meaning "knowledge") is a systematic enterprise that builds and organizes knowledge in the form of testable explanations and predictions about the universe. Sains didefinisikan sebagai sebuah usaha yang sistematis untuk membangun dan mengorganisasikan pengetahuan dalam sebuah bentuk penjelasan atau prediksi yang bisa diuji tentang alam semesta. Sebagian sains sudah ada sejak sebelum Islam datang. Sains tentang panjang sisi miring sebuah segi tiga siku-siku sudah ditemukan Phytagoras, matematikawan Yunani (wafat 495 SM). Sains tentang hidrolika sudah ditemukan Archimedes (wafat 212 SM). Sains tentang Astronomi sudah ditulis oleh Ptolemeus (wafat 168 SM). Sains tentang banyak hal dicoba dirumuskan oleh Aristoteles (wafat $322 \mathrm{SM}$ ). Beberapa jenis sains ini masih dicampuri berbagai mitos, filsafat, kecenderungan spiritual tertentu, aksioma yang tidak berdasar, atau harapan-harapan palsu. Astronomi masih dicampuri dengan ramalan nasib, dan ilmu kimia masih dicampuri dengan pembuatan ramuan sihir. Ketika Islam datang, Islam memberikan sejumlah hal, yang kemudian generasi selanjutnya mereview hubungan antara iman-Islam dengan sains. Dalam perkembangannya, teramati ada lima macam paradigma hubungan Islam \& Sains.

\subsubsection{Sains Sekuler}

Sains sekuler adalah sains yang mendominasi dunia saat ini, ketika sains sama sekali menolak untuk menerima keberadaan Tuhan. Akibatnya, Tuhan tidak boleh dibawa-bawa ketika menggeluti sains, dalam bentuk apapun, baik itu sekedar sebagai inspirator, pagar yang mengatur metode ilmiahnya, hingga aplikasi penemuannya. Ilmuwan yang masih melibatkan Tuhan dalam kajian ilmiahnya dianggap sebagai saintis yang tidak serius. Tuhan biarlah berada di tempat terhomat, yang tidak diganggu oleh rumus dan falsifikasi. Tuhan biarlah tetap di ujung lorong sana di tempat-tempat yang tidak bisa dikunjungi sains. Yang menyedihkan, sains sekuler ini diajarkan pada anak-anak kita di semua mata pelajaran, termasuk di pelajaran agama, dan termasuk di sekolahsekolah Islam.

\subsubsection{Islamisasi Sains}

Pola islamisasi sains sebenarnya baru muncul abad 20, ketika dunia Islam sudah tidak lagi memiliki ilmuwan-ilmuwan atau saintissaintis handal kelas dunia. Islamisasi Sains berusaha menjadikan penemuan-penemuan sains besar abad-20 yang mayoritas terjadi di Barat, dapat dimanfaatkan untuk meningkatkan keimanan umat Islam. Misalnya, penemuan ultrasonografi yang dapat melihat proses terbentuknya janin di dalam perut, atau penemuan kecepatan cahaya, diklaim sebagai telah disebutkan di dalam Qur'an, sehingga diharapkan makin mempertebal iman seorang muslim bahwa Qur'an telah mendahului sains, karena diturunkan oleh Allah Yang Maha Tahu. Inilah hubungan yang dikembangkan banyak muslim saat ini, dan yang menonjol adalah Harun Yahya. Hubungan ini mendapat banyak kritik, bahwa hubungan ini hanya sekedar menghubung-hubungkan hal-hal yang semula tidak berhubungan (othak-athik-gathuk), karena para ilmuwan muslim masa lalu pun tidak berpikir ke sana, dan hubungan ini belum berhasil mendorong kreatifitas muslim dalam meneliti atau mendapatkan fakta sains baru. Hubungan ini juga bisa berdampak negatif, ketika fakta sains yang dimaksud ternyata di masa depan harus dikoreksi secara signifikan, karena ada data atau model analisis yang baru.

Di luar paradigma ini ada usaha-usaha untuk "menggantikan" asumsi-asumsi dasar yang ada pada "sains-sekuler" saat ini dengan Islam. Misalnya mengganti "teori-kekekalan-massa-energi" di fisika, dengan alasan yang kekal hanya Allah. Tetapi sebenarnya penggantian asumsi ini tidak relevan dengan sains itu sendiri, karena yang dimaksud "kekekalan massa-energi" dalam fisika adalah "kekekalan pada skala laboratorium". Fisika tidak membahas dunia di saat penciptaan ataupun di saat kiamat nanti, karena tidak bisa diuji. Kita memang mengasumsikan bahwa hukum-hukum fisika yang kita kenal itu berlaku di seluruh jagad raya dan kapanpun. Mengapa? Karena kita tidak bisa mendapatkan hukum-hukum fisika lain di sesuatu yang tidak bisa kita hadirkan untuk diuji. Jadi asumsi dasar apakah dunia diciptakan Allah (sebagaimana keimanan seorang muslim) atau muncul dengan sendirinya (seperti keyakinan seorang atheis), tidak akan berpengeraruh pada rumusan hubungan antar fenomena alam semesta di dalam sains itu sendiri.

\subsubsection{Saintifikasi Islam}

Saintifikasi Islam juga baru muncul abad-20. Idenya adalah bagaimana agar perintah-perintah Islam dapat dipahami secara ilmiah. Misalnya bahwa tata cara sholat memang akan menghasilkan dampak positif secara fisiologis/psikologis, atau bahwa penerapan mata uang tunggal berupa dinar-emas/dirham-perak akan menghasilkan kondisi ekonomi yang terbaik. Contoh ilmuwan yang beberapa kali menggunakan paradigma hubungan ini adalah Prof. Dadang Hawari. Beliau melakukan riset yang mendalam dengan alat-alat pencatat denyut jantung (EKG) atau sinyal otak (EEG), juga mengambil sampel darah dan menganalisisnya, pada orangorang yang rajin melakukan sholat (khususnya tahajud) dan puasa. Secara umum sebagai upaya memuaskan rasa ingin tahu, hal ini sah-sah saja, dan juga diakui sebagai aktivitas saintifik. Hanya saja, hasil riset seperti ini tidak akan menambah atau mengurangi norma perintah/larangan yang diberikan oleh Islam. Aktivitas saintiifikasi Islam juga tidak produktif pada aspek-aspek yang didiamkan (tidak diatur secara tegas) oleh agama. 


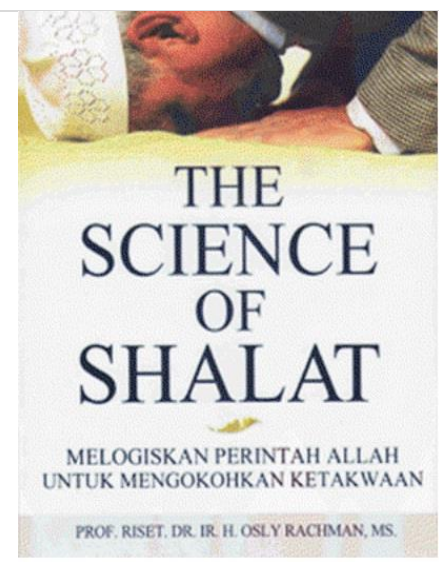

Gambar 2. Contoh buku dengan genre Saintifikasi Islam

\subsubsection{Sains Ta'wili}

Sains Ta’wili juga baru mengalami "kebangkitan" di abad-20. Bentuknya adalah menggali ayat-ayat Qur'an atau hadits Nabi, lalu mencoba membuat postulat yang dianggap ilmiah, dengan mengabaikan uji teori secara empiris atau eksperimen. Contohnya adalah, ketika ada ayat tentang "Matahari beredar ..." lalu "Bulan dan Bintang beredar ...", sedang tidak ada ayat yang berbunyi bahwa "Bumi beredar ...", maka mereka berkesimpulan bahwa pastilah Bumi ini pusat alam semesta. Kesimpulan ini jelas bertentangan dengan fakta-fakta keras yang menjadi dasar teknologi ruang angkasa saat ini. Tetapi para penganut sains ta'wili bersikukuh bahwa "Qur'an lah yang benar". Mereka mengabaikan kenyataan bahwa pendapat mereka itu hanyalah ta'wil, bukan Qur'an itu sendiri. Banyak hal yang tidak disebutkan di dalam Qur'an, dan itu tidak berarti tidak ada atau tidak akan pernah ada. Existensi es di kutub-kutub bumi tidak disebutkan di dalam Qur'an, tetapi faktanya kan ada. Demikian juga bahwa suatu ketika mahluk hidup bisa dikembangbiakkan dengan teknik "cloning", itu tidak berarti melawan ayat suci, karena sebenarnya Qur'an tidak pernah membicarakan hal itu. Sementara itu, di sisi sains juga banyak juga teori yang sebenarnya juga hanya ta'wil, bukan sains itu sendiri. Charles Darwin sebenarnya hanya mendapatkan fosil-fosil yang berbeda-beda dengan usia berbeda-beda, sehingga dia menyimpulkan adanya evolusi. Tetapi bahwa evolusi itu akan mengantarkan monyet menjadi manusia, tentu itu adalah ta'wil, karena tidak mungkin ada uji experimen untuk evolusi manusia. Waktu yang dibutuhkan akan sangat lama (ratusan ribu tahun). Di dunia Kristen, sains ta'wili atas Bibel mengantarkan mereka untuk menghukum para ilmuwan seperti Galileo atau Copernicus karena dianggap melawan ajaran gereja. Di dunia Islam, hal yang sama terulang sejak abad-20, ketika beberapa tokoh ulama di Saudi menggunakan sains ta'wili untuk menganggap kafir ilmuwan yang tidak percaya pada "teori Geosentris ala Islam". Belakangan lebih parah lagi, beberapa ulama bahkan meyakni bumi itu datar, dan orang yang meyakini bumi itu bulat tergolong kafir!

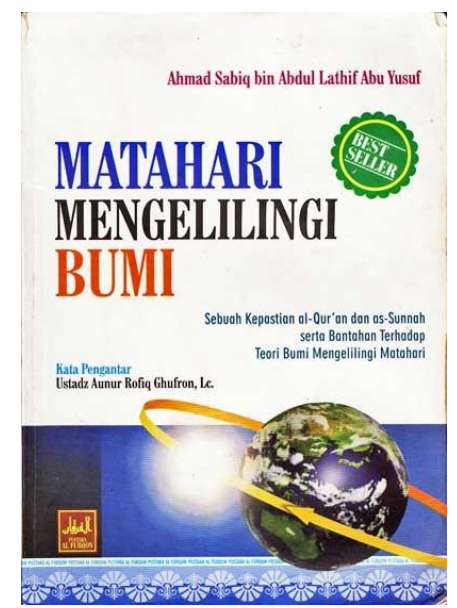

Gambar 3. Contoh buku dengan genre Sains Ta’wili

Contoh lain sains ta'wili banyak ditemui di dunia kesehatan. Ketika ada hadits shahih "Habatussaudah itu obat segala penyakit selain maut", maka pendukung sains ta'wili dengan serta merta yakin bahwa habatussaudah itu dapat mengobati penyakit yang sekarang belum ketemu obatnya, seperti HIV/AIDS, dan ketika penderita tersebut akhirnya mati juga (karena tidak sembuh), mereka berkilah, "ya itu karena maut memang tidak bisa diobati". Kalau seperti ini halnya, tentunya penyakit apapun bisa diklaim begitu saja. Yang jelas, perjalanan sejarah ilmuwan kedokteran salaf justru tidak seperti itu. Ibnu Sina, Abu Qasim az-Zahrawi atau Ibnu an-Nafs tidak berhenti dengan obat segala penyakit seperti habatussaudah. Mereka mengembangkan banyak hal, sampai ke pembedahan dsb, untuk menemukan metode pengobatan yang paling efektif, dan tidak membiarkan maut menjemput pasien, kecuali seluruh ikhtiar yang ilmiah sudah dikerjakan.

\subsubsection{Sains - Islam}

Sains-islam adalah Rasulullah sendiri yang ditunjukkan dalam hadits tentang kasus penyerbukan kurma, yang menunjukkan bahwa urusan sains \& teknologi adalah "urusan kalian". Nabi datang dengan membawa wahyu adalah untuk mengatur pandangan, sikap atau perilaku manusia yang tidak bisa ditemukannya sendiri dengan sains. Qur'an bicara hal-hal ghaib tentang masa lalu yang sangat jauh saat penciptaan bumi \& langit, saat penciptaan manusia, atau masa depan yang juga sangat jauh, saat bumi \& langit digulung lalu semuanya dibangkitkan kembali untuk menghadapi pengadilan. Ini adalah hal-hal yang tidak mungkin diuji 
JKPIs, Vol. 1 No. $1,2018 \mid 22$

dengan sains, tetapi hanya dapat diketahui dari kabar di dalam Qur'an. "When the science end, begin the faith". Islam memberikan kepada manusia berberapa norma perilaku yang halal dan haram, bukan atas dasar pembuktian sains, tetapi atas dasar kepatuhan kepada Tuhan selaku pencipta manusia. Bahwa di balik halal - haram itu bakal ada hikmah pada jangka panjang, bisa saja, tetapi itu bukan dasar diberlakukannya norma tersebut. Seorang muslim mematuhi norma itu karena keimanannya, bahwa Allah yang Maha Tahu, pasti tidak akan memberikan perintah yang tidak memberikan manfaat pada jangka panjang, sekalipun kita belum tahu secara saintifik.

Karena itu, para ilmuwan generasi salaf, menjadikan Islam sebagai motivator mereka mencari ilmu - bahkan sampai ke Cina, atau inspirator dalam menggali objek-objek yang hanya disinggung selintas di dalam Qur'an. Mereka mendalami astronomi berawal dari buku Almagest karya Ptolemeus, lalu dikembangkannya sendiri dengan membangun banyak observatorium, karena dorongan ayat surat Al-Ghasiyah "Apakah mereka tidak memperhatikan, bagaimana langit ditinggikan?". Mereka menjadikan syariat Islam sebagai pagar tentang apa yang boleh dan apa yang tidak boleh selama mencari ilmu itu. Maka mereka yakin bahwa ilmu sihir tidak boleh dipelajari, meski ada rasa ingin tahu yang besar, karena ilmu itu menuntut dipelajari dengan praktikum yang melanggar syariat dan penuh kesyirikan. Dan mereka juga menjadikan Islam sebagai arah bagaimana ilmu itu diamalkan. Para ilmuwan muslim selalu berusaha keras agar setiap rumus hukum alam yang mereka temukan, atau setiap senyawa kimia yang berhasil direkayasa, dapat menjadi berkah dan investasi pahala yang mengalir terus meski ditinggal mati. Sains dan teknologi tidak dikembangkan untuk menjajah manusia, tetapi untuk menjadi rahmat bagi seluruh alam. Inilah hubungan model SAINS - ISLAM ala Ibnu Sina, Al-Biruni, Ibnu al-Haitsam, Muhammad al-Khawarizmi, Ibnu Khaldun, dan sebagainya.

Dalam beberapa disiplin ilmu sosial, seperti sosiologi, ekonomi, hukum atau politik, sebagian fenomena empiris dapat dipelajari dengan paradigma sains - islam. Namun solusi atas persoalan yang dihadapi akan diberikan tidak hanya semata-mata berdasarkan temuan empiris tetapi juga berdasarkan pandangan hidup dan syariat Islam. Maka sains Islam ini menjadi SAINS IJTIHADI. Kajian atas hal-hal ini menjadikan saintis muslim dituntut memahami metode penelitian empiris dan sekaligus paham mendudukkan nash-nash Qur'an dan Hadits dalam konteks keilmuan.

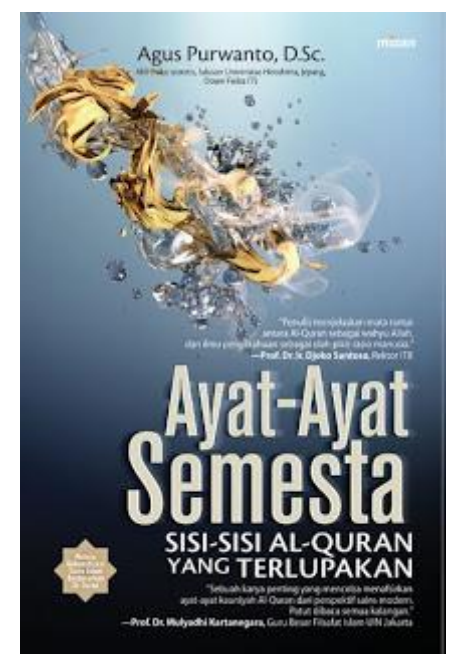

Gambar 4. Contoh buku dengan genre Sains Islam

Sebagian orang mengalami kesulitan membedakan paradigma-5 (SAINS ISLAM) dengan paradigma-1 (SAINS SEKULER). Sebagian penganut paradigma-4 (SAINS TA'WILI) bahkan menuduh praktisi paradigma-5 telah terjebak dalam sekulerisme, karena dianggap menolak dalil wahyu yang pasti benar, padahal yang disangka dalil itu masih mutasyabihat. SAINS ISLAM sangat berbeda dengan SAINS SEKULER di tiga hal, yaitu (1) inspirasi/motivasi mengembangkan sains, (2) metode mengembangkan sains, (3) pembatasan dalam aplikasi sains, yaitu teknologi/inovasi. Hasilnya: SAINS ISLAM akan jauh lebih berkah, karena didorong oleh semangat mensyukuri kebesaran Allah dan semangat menjadikan umat Islam umat terbaik bagi manusia, bukan semangat exploitasi manusia atas manusia lain; dikembangkan dengan mematuhi hukum syara', bukan mengabaikannya; dan diterapkan untuk merahmati seluruh alam, bukan untuk menjajah.

\section{KESIMPULAN}

Sains dan Teknologi yang diterapkan dalam paradigma sekuler akan menjajah, atau lambat atau cepat merusak keberlanjutan kehidupan melalui kerusakan lingkungan hidup. Sementara umat Islam di negeri-negeri Islam yang tidak menguasai sains dan teknologi de facto akan terus terjajah, baik secara ekonomi maupun politik. Hanya sains dan teknologi yang dikembangkan dengan paradigma Islam di dalam tatanan sistem Islam yang akan membebaskan dunia dari penjajahan.

\section{REFERENSI}

Abdurrahman, M. (2002). Rahasia Di Balik Keteraturan dan Keganjilan Alam Semesta (judul asli: Rational Universe, Irrational Odds). Bogor, Pustaka Thariqul Izzah.

Al-Faruqi, I.R., Al-Faruqi, L.L. (1986). Atlas Budaya Islam, Menjelajah Khazaha Peradaban Gemilang (judul asli: The Cultural Atlas of Islam). Bandung: Mizan.

Amhar, Fahmi (2011). TSQ edisi 2, 50 Kisah-kisah Penelitian dan Pengembangan Sains dan Teknologi di Masa Peradaban Islam. Al Azhar Press.

An Najar, Zaghlul (2006). Pembuktian Sains dalam Sunnah (judul asli: Al I'jaz Al-'Ilmu fi As-Sunnah An Nabawiyah) 3 juz. Amzah, Jakarta.

As-Sirjani, Raghib (2011). Sumbangan Peradaban Islam pada Dunia (judul asli: Madza Qaddamal Muslimuna lil 'Alam Ishamaatu alMuslimin fi al-Hadharah al-Insaniyah). Jakarta: Pustaka Al-Kautsar.

Basya, F. (2000). Matematika Islam: Sebuah Pendekatan Rasional untuk Yaqin. Penerbit Republika. ISBN9793210400. 
JKPIs, Vol. 1 No. 1, 2018| 23

Bünder, W., Häußler, P., Lauterbach, R., Mikelskis, H. (1987). Jugendlexikon Technik Menschengerechte und naturvertragliche Technologien. Rowohlt Taschenbuch, Frankfurt,

Diamar, S. (2009). Cara Baru Membangun Negeri. Indonesia Bebas Miskin 2015 Negara Maju 2020 Negara Maju dan Kuat 2025. Jakarta: Universitas Indonesia Esa Unggul.

Georgiadou, Y. (2013). Empowering Citizen - Engaging Society. Proceeding of ISDE Symposium, Kuching, Malaysia.

Handayu, T. (2001). Memaknai Cerita, Mengasah Jiwa. Panduan Menanamkan Nilai Moral pada Anak melalui Cerita. Era Intermedia, SoloAnsary.

Hassan, A.Y, Hill, D.R. (1993). Teknologi dalam Sejarah Islam (judul asli: Islamic Technology: An Illustrated History). Bandung: Mizan.

Hidayat N. (1982). Karsa menegakkan jiwa agama dalam dunia ilmiah. Versi baru Ihya Ulumiddin.

Hunke, S.(1960). Allahs Sonne ueber dem Abendland. Fischer Taschenbuch Verlag GmbH, Frankfurt am Main, 1990.

Iskan, D.(2012). Manufacturing Hope Bisa. Elex Media Komputindo, Jakarta.

Kemenristek (2006). Laporan Survei Lembaga Litbang Pemerintah tahun 2005.

Khan, A.(2009). Constructing an Industialised Muslim World. Khilafah.com.

Purwanto, A. (2008). Ayat-Ayat Semesta: Sisi-Sisi Al Quran yang Terlupakan. Bandung: Penerbit Mizan.

Rachman, O. (2011). The Science of Shalat. Qultum Media.

Rahman, A. (1981). Ensiklopediana Ilmu dalam al-Qur'an (judul asli: Quranic Sciences). Bandung: Penerbit Mizania.

Robinson, F. (1982). Atlas of the Islamic World since 1500. Oxford.

Ruskanda, S. F. (1998). Pancapaian Ilmu LIPI selama Pelita VI (1993-1997) (Suatu Model Evaluasi). Lembaga Ilmu Pengetahuan Indonesia.

Sabiq, A. (1427 H). Matahari Mengelilingi Bumi. Sebuah Kepastian al-Qur'an dan as-Sunnah serta Bantahan Terhadap Teori Bumi Mengelilingi Matahari. Pustaka Al-Furqon.

Saefudin, D. (2002). Zaman .Keemasan Islam. Rekonstruksi Sejarah Imperium Dinas Abbasiyah. Grasindo.

Saputra, D., Handoyo, S., Pariaman, P., Prasetyas, V.R. (2005). Kajian Jejaring dalam Mendukung Sistem Inovasi Nasional. LIPI Press, 2005.

Susanto, H. (2015). Tuhan Pasti Ahli Matematika.

Tamim (2009). Dari Puncak Baghdad, Sejarah Dunia versi Islam (judul asli: Destiny Disrupted: A History of the World through Islamic Eyes). Zaman, Jakarta.

Yahya, H. (2008). Keajaiban al-Qur'an (judul asli: Miracles of the Qur'an). Bandung: Arkan Publishing. 